\title{
Analisis Pengaruh Angin dan Arus Terhadap Olah Gerak MT.GANDINI Saat Akan Sandar Di Pelabuhan Pertamina Balikpapan
}

\author{
Muh. Aldy Subar ${ }^{1)}$ Arlizar Djamaan²) Muhlis Muhayyang ${ }^{3)}$ \\ Politeknik IImu Pelayaran Makassar \\ Jalan Tentara Pelajar No. 173 Makassar, Kode pos. 90172 Telp. (0411) \\ 361697975; Fax (0411) 3628732 \\ E-mail: pipmks@pipmakassar.com
}

\begin{abstract}
ABSTRAK
Kemampuan olah gerak kapal akan dipengaruhi oleh dua faktor dari luar, yaitu keadaan laut dan keadaan perairan. Adapun tujuan dari penelitian ini ialah mengetahui pengaruh angin dan arus terhadap olah gerak kapal MT.GANDINI pada saat akan sandar. Hal ini untuk memberikan informasi tentang bagaimana mengolah gerak kapal agar keselamatan pelayaran dapat tercapai. Penelitian ini dilaksanakan di atas kapal MT. GANDINI salah satu armada milik PT. BULL pada saat penulis melaksanakan praktek laut (PRALA). Data diperoleh dengan cara melakukan pengamatan dan wawancara pada pihak yang bersangkutan serta kajian literatur yang berkaitan dengan judul skripsi. Hasil dari penelitian ini menunjukkan bahwa pada saat berolah gerak banyak faktor yang harus diperhatikan oleh perwira di atas kapal khususnya keadaan angin dan arus, terbukti bahwa kapal terdorong oleh arus sehingga hampir bersenggolan dengan kapal yang sedang berlabuh jangkar. Hal ini menunjukkan bahwa, kecepatan dan arah angin serta arus sangat berpengaruh terhadap pergerakan kapal pada saat akan sandar di pelabuhan
\end{abstract}

Kata Kunci : MT.GANDINI, Olah Gerak, Angin, Arus, sandar 


\section{PENDAHULUAN}

\subsection{Latar Belakang}

Kemampuan Olah Gerak kapal akan dipengaruhi oleh factor dari luar. Faktor yang datangnya dari luar kapal, mencangkup dua hal penting yaitu keadaan laut dan keadaan perairan.Karena factor pentingnya dan strategisnya jasa angkutan laut, perlu diselenggarakan tindakan untuk pencegahan dan pembelajaran terhadap kecelakaan kapal dan insiden kapal lainnya, hal ini bertujuan agar factor dan penyebab kecelakaan yang sama tersebut tidak terulang kembali. Sedemikian pentingnya pengetahuan mengolah gerak kapal demi menjaga keselamatan pelayaran, maka setiap awak kapal yang bersangkutan perlu dibekali pengetahuan untuk menjaga keselamatan kapalnya dari segala pengaruh dari luar seperti ombak, dan angin.Agar keselamatan pelayaran dapat tercapai,maka perlu bagi para cadet yang akan melakukan praktek untuk melakukan penganalisaan yang berjudul "Analisis Pengaruh Angin dan ArusTerhadap Olah Gerak Kapal MT.GANDINI pada saat akan Sandar di Pelabuhan Pertamina Balikpapan".

\subsection{Rumusan Masalah}

Berdasarkan dari uraian latar belakang di atas, maka permasalahan yang akan dibahas yaitu bagaimana pengaruh angin dan arus terhadap olah gerak kapal MT.GANDINI pada saat akan sandar di pelabuhan Pertamina Balikpapan.

\subsection{Tujuan Penelitian}

Adapun tujuan dilakukannya penelitian ini adalah mengetahui pengaruh angin dan arus terhadap olah gerak kapal MT.GANDINI pada saat akan sandar di pelabuhan Pertamina Balikpapan.

\subsection{Manfaat Penelitian}

Hasil penelitian ini diharapkan mempunyai manfaat ganda, baik manfaat praktis maupun manfaat teoritis sebagai berikut: 


\section{SecaraTeoritis}

Sebagai bahan masukan bagi pelaut khususnya perwira dek agar terhindar dari bahaya tubrukan pada saat berolah gerak.Sebagai gambaran dan penjelasan bagi pembaca untuk mengetahui dan memahami pengaruh angin dan arus terhadap olah gerak kapal.

2. SecaraPraktis

Agar perwira dek dalam setiap melaksanakan Olah Gerak dari Pengaruh Angin dan Arus mampu menghindari bahaya tubrukan pada saat proses sandar di pelabuhan.

\section{TINJAUAN PUSTAKA}

\subsection{Olah Gerak}

Menurut Tim-Ikip Semarang (1998:1) Mengolah gerak kapal dapat diartikan sebagai menguasai kapal baik dalam keadaan diam maupun bergerak untuk mencapai tujuan pelayaran dan seefisien mungkin dengan mempergunakan sarana yang terdapat di kapal itu seperti mesin, kemudi dan lain-lain.Olah gerak kapal sangat tergantung pada bermacam-macam faktor misalnya tenaga penggerak, kemudi, bentuk badan kapal, sehubungan dengan kedalaman air sekitarnya, keadaan arus atau pasang surut air. Tentu saja dalam mengolah gerak kapal yang satu akan berbeda dengan yang lain, meskipun demikian, prinsip-prinsip olah gerak kapal dan memperhatikan dengan seksama olah gerak kapal pada setiap kesempatan, akan dapat mengenal dan membawa kapal dengan baik.

Menurut Rozari (1982:2), olah gerak sebetulnya mengandung pengertian tentang kemampuan sebuah kapal untuk merubah sebuah kedudukannya dari suatu tempatketempat lain yang dikehendaki.

Menurut Widarbowo, (2011:83) yang dimaksud dengan angin adalah udara yang bergerak akibat adanya perbedaan tekanan udara dengan arah aliran dari tempat yang memiliki tekanan tinggi ke tempat 
yang bertekanan rendah atau dari daerah yang memiliki suhu/temperatur rendah ke wilayah bersuhu tinggi.

Menurut Gross(1972), arus adalah pergerakan massa air laut yang menyebabkan perpindahan horizontal dan vertikal massa air laut tersebut yang terjadi secara terus. Sedangkan menurut Hutabarat dan Evans (1984), arus merupakan gerakan air yang terjadi pada seluruh lautan di dunia.

Faktor dari luar adalah faktor yang datangnya dari luar kapal, mencakup dua hal penting yaitu keadaan laut dan keadaan perairan. Hal ini perlu dipahami, mengingat keterbatasan kemampuan kapal dalam menghadapi cuaca maupun laut yang berbeda-beda, serta gerakan kapal di air juga memerlukan ruang gerak yang cukup besar.

Faktor dalam yang bersifat ialah bentuk kapal, macam dan kekuatan mesin kemudian faktor dalam yang bersifat tidak tetap ialah sarat kapal, trim dan list kapal serta alur pelayaran.

\subsection{Menyandarkan Kapal Pada Dermaga}

Kapal sandar di dermaga diartikan sebagai diikat dengan tali kapal (mooring lines) sedemikian rupa sehingga kapal tidak bergerak lagi. Yang dimaksud dengan dermaga disini adalah tempat sandar kapal. Untuk membuat kapal tidak bergerak maju dan mundur selama kapal di dermaga maka dipasang head / bow line dan stern line. Head line atau tali depan adalah tali yang dipasang di haluan kapal, mengarah ke depan. Stern line (tali belakang) adalah tali yang dipasang diburitan kapal, mengarah kebelakang. Breast line (tali melintang) adalah tali yang digunakan untuk menjaga agar kapal tidak bergerak menjauhi dermaga. Spring line (tali spring) adalah tali yang dipasang di haluan mengarah ke depan disebut spring belakang. Spring lines ini berfungsi sebagai penahan, agar kapal tidak bergerak kedepan dan ke belakang, fungsinya sama dengan head dan stern lines tapi spring lebih efisien. Breast dan spring lines ini dipasang di beberapa tempat dikapal tergantung dari besarnya kapal, 
misalnya di pasang di bow (haluan), waist (tengah-tengah kapal), dan diberi nama sesuai dengan itu.

Bila angin datang dari darat, maka untuk merapatkan kapal didermaga akan memerlukan banyak tenaga. Kapal diikat dengan tros yang kuat, pada bagian antara tengah kapal dan buritan kedermaga.Tros di hibob kencang bersama dengan mesin maju pelan dan kemudi diatur sedemikian hingga kapal dapat ditahan dalam keadaan sejajar dengan dermaga. Setelah kapal merapat, segera kirim tros yang lain terutama tros melintang kapal (breastline). Pada kapal - kapal besar hal ini tidak dapat dilakukan, sebab kemungkinan besar tros akan putus. (Olah Gerak dan Pengendalian Kapal: 2015).

Olah gerak bila angin dari laut dapat dilakukan dengan mempergunakan pelampung kepil yang ada di tengah perairan, atau dibantu dengan jangkar apabila pelampung kepil semacam itu tidak tersedia. Pelampung kepil Ididekati dengan hati hati, kecepatan secukupnya untuk olah gerak. Sudut antara haluan dengan dermaga cukup besar, serta pelampung berada pada lambung kanan kapal. Kirim tros depan ke pelampung 1 dan di ikat. Setelah itu jika memungkinkan kirim tros belakang ke pelampung II Apabila masih terlalu jauh jaraknya, dibantu dengan mesin mundur, area tros depan untuk mendekatkan buritan ke pelampung II. Oleh karena pengaruh angin, maka kapal akan bergeser ke arah dermaga. Area tros muka dan belakang pelan secara bersama-sama sampai kapal sandar di dermaga dengan baik. (Olah Gerak dan Pengendalian Kapal: 2015).

Olah gerak bila arus dari depan dilakukan dengan cara kapal di geserkan pelan-pelan ke kiri, serta mempergunakan arus untuk membantu proses pendekatan kapal ke dermaga.Seperti biasa, jangkarpun disiapkan, dalam hal ini adalah jangkar kanan sewaktu-waktu, bila di perlukan dapat di pergunakan dengan segera.Kapal mendekati dermaga dengan posisi sejajar, kecepatan di atur agar kapal masih dapat bergerak terhadap arus. (Buku Olah Gerak dan Pengendalian Kapal: 2015). 
Karena suatu alasan tertentu olah gerak dalam kondisi arus dari belakang biasanya hanya dilakukan dalam keadaan terpaksa, harus hatihati dan cepat. (Buku Olah Gerak dan Pengendalian Kapal: 2015)

\section{METODE PENELITIAN}

Waktu penelitian adalah pada saat penulis melakukan praktek laut selama 12 bulan 1 hari di MT. GANDINI sebagai kadet deck. Sign on pada tanggal 05 Mei 2018 dan sign off pada tanggal 08 Mei 2019. Lokasi penelitian ini dilaksanakan di kapal MT. GANDINI milik perusahaan PT.BULL MANAGEMENT.

Metode penelitian yang digunakan penulis untuk menganalisis data yang ada dalam skripsi ini adalah metode deskriptif kualitatif.

Teknik pengumpulan data ini dilakukan dengan cara observasi, wawacara/interview dan kajian pustaka.

\section{HASIL DAN PEMBAHASAN}

\subsection{Analisis Data}

Pada proses sandar ini, MT. GANDINI akan sandar kanan mengikuti arus melewati MV. Samudra Bangsa yang sedang berlabuh jangkar. MT. GANDINI yang sedang berolah gerak hanyut terbawa arus mendekati MV. Samudera Bangsa. MT. GANDINI yang bermuatan penuh dengan draft 9 meter yang sedang berolah gerak semakin terdorong arus yang berasal dari selat laut Kalimantan Selatan hingga jarak dari MT. GANDINI dengan kapal MV. Samudra Bangsa sekitar 30 meter. Situasi di anjungan pada saat itu tegang, kapal tug boat yang menunda pada haluan dan buritan tidak kuat mendorong kapal yang hanyut dan bermuatan penuh. Nakhoda meminta izin kepada pandu untuk mengambil alih pimpinan dari pandu. Nakhoda memerintahkan tug boat yang menunda di buritan agar segera berlindung di buritan MT. GANDINI dan nakhoda memerintahkan kepada mualim 4 untuk maju penuh dan setelah beberapa detik nakhoda memerintahkan kepada juru mudi untuk cikar kiri sehingga buritan membuka keluar. Nakhoda juga melakukan komunikasi dengan 
nakhoda MV. Samudera Bangsa melalui radio VHF (very high frequency) untuk berjaga-jaga dengan mempersiapkan kemudi kapal tersebut untuk berolah gerak membelokkan kekanan mengikuti pergerakan MT. GANDINI agar lambung kiri MT. GANDINI terbebas dari kapal MV. Samudera Bangsa. Usaha yang dilakukan oleh nahkoda cukup berhasil karna dapat menghindarkan MT. GANDINI dari bahaya tubrukan yang fatal.

Arah arus dan angin yang tidak diperhatikan oleh perwira di MT. GANDINI yang menyebabkan kapal hampir mengalami senggolan dengan MV. Samudera Bangsa. Cara mengetahui arah angin dapat diketahui dengan melaksanakan pengamatan secara langsung pada wind direction indicator yang berada di anjungan. Maka akan segera diketahui arah angin. Berdasarkan hasil observasi, angin pada saat itu adalah $20^{\circ}$ kiri dari haluan kapal, pada saat itu haluan kapal, adalah $70^{\circ}$. Angin bertiup dari arah $250^{\circ}$ Northwest atau barat laut. Dalam proses sandar kecepatan angin terbaca pada wind speed indicator yang terletak di anjungan adalah 15 knot.

Arah arus pada tanggal tanggal 11 maret 2018 di selat laut (Kalimantan Selatan) pada pukul 10.00 WITA arus menuju kearah $258^{\circ}$ dengan kecepatan arus 0,5 knot.

Gambar 1: Cara Menentukan Arus

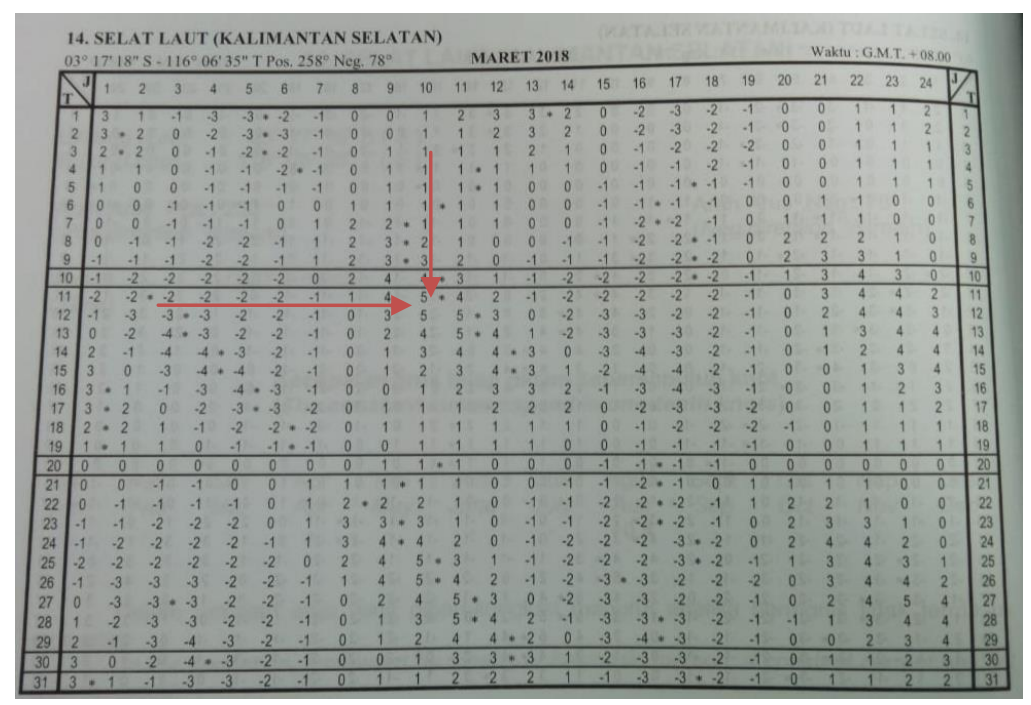

Sumber: Buku Tidal Stream Table 2018 


\subsection{Pembahasan}

Salah satu faktor yang menyebabkan kapal bersenggolan dengan kapal lain adalah perwira MT. GANDINI tidak memperhatikan arah angin dan arus dengan benar. Dikatakan memperhatikan arah angin dan arus karena pada saat insiden terjadi angin bertiup dari arah barat laut menuju tenggara dan arus dari arah tenggara kearah barat laut. Sedangkan proses sandar yang baik adalah melawan arah arus agar tidak mudah hanyut. Seharusnya MT. GANDINI berolah gerak mengambil buritan MV. Samudra Bangsa dan melakukan sandar kiri. Selain itu perlu diketahui bahwa pada saat akan sandar di pelabuhan pertamina Balikpapan arus dan angin sangat kencang karena letaknya berada di muara sungai selat laut (Kalimantan Selatan).

\section{SIMPULAN DAN SARAN}

\subsection{Simpulan}

Olah gerak kapal MT. GANDINI pada saat sandar di pelabuhan Pertamina Balikpapan dipengaruhi oleh dua faktor dari luar yakni keadaan laut dan keadaan perairan.

\subsection{Saran}

Diharapkan dengan penelitian ini bisa menjadi tolak ukur kepada perwira kapal pada saat akan sandar di pelabuhan. Supaya lebih memahami dan memperhatikan dengan teliti kondisi angin, arus dan kondisi kapal, sebagai persiapan yang penting sebelum sandar. 


\section{DAFTAR PUSTAKA}

Dinas Hidrografi dan Oseanografi TNI Angkatan Laut.(2015). Daftar arus pasang surut tidal stream table. Jakarta

Hutabarat dan Evans. (1984). Pengertian Arus Laut (Online) http://www.pengertianilmu.com diakses pada tanggal 16 September 2018

Istopo. (2001). Olah Gerak dan Pengendalian Kapal. Jakarta : Koperasi Pegawai BP3IP Sejahtera.

Politeknik IImu Pelayaran Makassar.(2012). Pedoman penulisan Skripsi.

Makassar : Politeknik IImu Pelayaran Makassar.

Tim FIP-IKIP Semarang.Olah Gerak kapal. Semarang : FIP-IKIP Semarang.

Widarbowo, D. (2011:83) Pengertian Angin (Online)

http://www.seputarilmu.com diakses pada tanggal 16 September $\underline{2018}$ 